TREE-RING RESEARCH, Vol. 62(1), 2006, pp. 3-12

\title{
ROOT-ZONE HYDROLOGY: WHY BALD CYPRESS IN FLOODED WETLANDS GROW MORE WHEN IT RAINS
}

\author{
GREGG R. DAVIDSON,* BRIAN C. LAINE \\ University of Mississippi \\ Department of Geology and Geological Engineering \\ Carrier 118 \\ University, MS 38677, USA
}

STANLEY J. GALICKI

Millsaps College

1701 N. State St.

Jackson, MS 39210, USA

and

STEPHEN T. THRELKELD

University of Mississippi

Department of Biology

University, MS 38677, USA

\begin{abstract}
Bald cypress (Taxodium distichum) is known to respond to increases in precipitation with increased radial growth even when rooted in continuously saturated sediments where water is not a growth-limiting factor. Measurements of $\delta^{18} \mathrm{O}, \mathrm{Cl}^{-},{ }^{3} \mathrm{H}$ and hydraulic head in surface water and shallow groundwater in an oxbow lake-wetland in northern Mississippi show that rapid downward flow of surface water into the root zone is initiated only after precipitation-induced increases in surface water depth exceed a threshold value. Rapid flow of surface water through the root zone has the potential to introduce oxygen to sediments that would otherwise be anoxic, facilitating nutrient uptake and growth. Climatic reconstruction using tree rings from bald cypress in this environment appears possible because increases in precipitation generally correlate well with increases in water level, which in turn enhances the delivery of oxygenated water to the roots.

Keywords: bald cypress, precipitation, growth, hydrology, wetland, oxbow lake, climate, tree rings
\end{abstract}

\section{INTRODUCTION}

The predictable relationship between water availability and radial growth in many tree species has made it possible to use relative changes in tree-ring widths as an excellent surrogate for past climate variation. The strongest correlations between precipitation and growth are typically associated with trees growing in well-drained, xeric soils where limited water availability during droughts inhibits growth (Douglass 1941; Fritts

*Corresponding author, davidson@olemiss.edu
1991). Wetland trees rooted in soils flooded much or all of the year would not intuitively be expected to respond to precipitation with increased growth, yet strong precipitation-growth relationships have been repeatedly documented for bald cypress (Taxodium distichum (L.) Rich) in wetlands throughout the southeastern United States (Stahle et al. 1985, 1988; Stahle and Cleaveland 1992; Galicki 2002).

When water is not a growth-limiting factor, the relationship between radial growth and precipitation must be indirect. Stahle and Cleaveland 
(1992) suggested that during periods of prolonged inundation, growth is linked to precipitation-induced changes in water chemistry, particularly the concentration of nutrients and dissolved oxygen. Oxygen facilitates nutrient uptake and growth in bald cypress (Dickson and Broyer 1972; Dickson et al. 1972; Pezeshki and Santos 1998), and precipitation adds oxygenated water to wetland surface waters. Stahle and Cleavland (1992) further noted that the fine root hairs responsible for much of the water and nutrient uptake in bald cypress are concentrated in the upper 10 to $30 \mathrm{~cm}$ of sediment where there is greater opportunity to access oxygen and nutrient additions at the surface. In continuously flooded systems, bald cypress may also develop adventitious roots and extend subsurface roots upward into the water column.

Roots positioned in surface water can take direct advantage of the delivery of oxygenated precipitation falling or flowing into the wetland. Where roots are limited to the subsurface, delivery of oxygen and nutrients to roots can occur by either downward diffusion from overlying water, or by advective flow of water through the root zone. The close temporal association of tree growth with precipitation from the same year, and often higher correlations with precipitation that occurs during the primary growing season in the spring (Stahle and Cleaveland 1992, 1996) suggests that delivery of oxygen or nutrients to the root zone is faster than feasible by diffusion alone. In flooded soils, dissolved oxygen concentrations typically decline rapidly with depth because of the high rate of oxygen consumption through biological activity and the slow rate of diffusion through saturated pores. Oxygen depletion can easily occur within the top few millimeters (Howeler and Bouldin 1971; Howeler 1972) resulting in redox conditions detrimental to root growth (Pezeshki 1991).

Advective flow of surface water has the potential to deliver a much greater flux of oxygen and nutrients to the root zone. Downward flow could be induced by an increased vertical gradient created by rising surface-water level following precipitation, or a rising water table surrounding a wetland could induce upward flow of oxygenated groundwater through the sediments (Davidson et al. 2005). The potential for and direction of ad- vective vertical flow will vary with the local hydrogeologic setting. The occurrence of vertical flow in some places and not in others may partially account for the conflicting results reported by various researchers investigating relative growth rates of mature bald cypress in well-drained, frequently flooded, and continuously flooded environments (e.g. Keeland and Sharitz 1995; several older studies discussed in Young et al. 1995; Conner et al. 1997; Van Arsdale et al. 1998).

The objective of our study was to determine if precipitation-driven increases in water level in a cypress wetland induced or substantially increased vertical flow of water and dissolved material through the root zone in a manner that could account for the observed correlation between tree growth and precipitation in continuously or nearly continuously flooded wetlands. A wetland in Mississippi was chosen containing both frequently and continuously flooded bald cypress trees where a correlation between tree growth and precipitation was previously documented $\left(\mathrm{r}^{2}=0.42\right.$ over last four decades (Galicki 2002)).

\section{Study Site}

Sky Lake is an oxbow lake-wetland located approximately $10 \mathrm{~km}$ north of the town of Belzoni, Mississippi (Fig. 1). This area is part of the ancestral floodplain of the Mississippi-Ohio River system, characterized by extremely low relief and numerous oxbow lakes. The lake receives runoff from a watershed of approximately 1,900 ha through several small ephemeral and perennial streams and by direct overland flow. Outflow from Sky Lake passes through Wasp Lake and into the Yazoo River.

A forested wetland, up to $1 \mathrm{~km}$ in width, surrounds the perimeter of Sky Lake. The land surrounding the wetland was cleared for agricultural use in the late 19th Century. The wetland is typically inundated continuously at the lower elevations, although local residents claim the lake has been known to go completely dry (Mark Simmons, personal communication). The dominant canopy species include bald cypress (Taxodium distichum), water tupelo (Nyssa aquatica), and wa- 


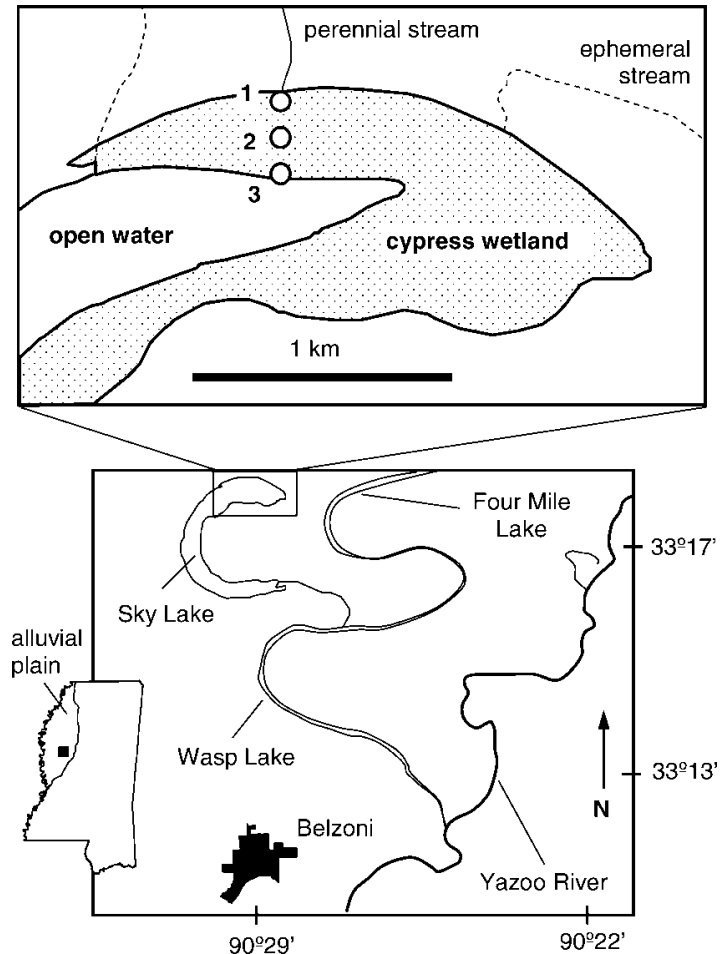

Figure 1. Sky Lake, Mississippi. Numbered points identify the location of piezometer nests. The alluvial plain identified in the state of Mississippi map is the ancient floodplain of the Mississippi-Ohio River system.

terlocust (Gleditsia aquatica). Cypress knees are abundant, but adventitious roots are not common.

The lake and wetland bottom elevation varies by approximately $1 \mathrm{~m}$ within the study area, and lies 4 to $6 \mathrm{~m}$ below the surrounding land surface. Sky Lake is hydrologically perched above a regional water table that lies well below the lake bottom (Arthur 2001). Prior to heavy pumping for agricultural use, the regional water table was higher (Fisk 1944; Brown 1947) and may have had periodic direct connection with the lake.

\section{METHODS}

Piezometer nests were installed in the wetland to monitor vertical and horizontal hydraulic gradients, and changes in shallow groundwater chemistry and isotopic composition. Three piezometer nests were installed along a north-south transect near the discharge point of a small unnamed pe- rennial stream (Fig. 1). The nests were separated from each other horizontally by $180 \mathrm{~m}$. Surface elevation declined from Nest 1 to Nest 3, with approximately $0.5 \mathrm{~m}$ of vertical change between each site. Each nest contained six piezometers: three at depths of 1.0, 2.0 and $3.0 \mathrm{~m}$ for monitoring hydraulic head, and three at depths of $0.25,0.50$ and $0.75 \mathrm{~m}$ dedicated for water chemistry and isotope sampling. The deeper piezometers were constructed from $2.5 \mathrm{~cm}$ (1 in.) PVC pipe; the shallower piezometers were constructed from $3.8 \mathrm{~cm}$ (1.5 in.) PVC pipe. All six were screened over the bottom $15 \mathrm{~cm}$ with slit widths of approximately $0.3 \mathrm{~mm}$.

Piezometers were installed without drilling by pushing to the desired depth. To prevent loss of the natural seal above the screen, the six piezometers were secured to a rigid center post made from a $10 \mathrm{~cm}$ (4 in.) diameter PVC pipe that was pushed to a depth of $75 \mathrm{~cm}$ and extended $1 \mathrm{~m}$ above the ground. The piezometers extended above the ground surface by at least $5 \mathrm{~m}$ to ensure that they would not be submerged when lake levels rose. A rope was fastened to the top of each piezometer and tied off to an overhead branch to further ensure that the piezometers would not move at ground level.

The three deeper piezometers in each nest contained a dedicated data-logging, non-vented pressure transducer. Head measurements were recorded hourly. Pressure transducer data was corrected for barometric variation using an additional pressure transducer installed above the high water line.

Water samples for chemical and isotopic analysis were collected every two weeks from the shallow piezometers. Water samples were not drawn from the same piezometers where head was monitored because head recovery was typically longer than the two week sampling interval (Laine 2004). Removal of water from the shallow piezometers caused no measurable change in head in any of the deeper piezometers. Most of the piezometers could not be purged without pumping them dry, so water was extracted directly from the screened interval without purging using a peristaltic pump. The first $20 \mathrm{~mL}$ of water from the pump was discarded to eliminate mixing with residual water in the tubing from the previous sample collection. Multiple 
samples were collected each time when sufficient water volume was available. Isotope samples were collected using $30-\mathrm{mL}$ glass bottles with polyseal closures; $\mathrm{Cl}^{-}$samples were collected in separate 60-mL polyethylene bottles. A third sample was collected for cation analysis, but data are not presented here because the results were largely redundant with the $\mathrm{Cl}^{-}$results (Laine 2004). The last water pumped was directed through a small closed cell housing Eh and $\mathrm{pH}$ probes. Water yields were often insufficient to collect and measure all desired parameters.

Water samples were also collected every two weeks from surface water when present at each piezometer nest and from a precipitation collection station set up near the high water line. A 1-L glass bottle was used to collect precipitation. A $0.5-\mathrm{cm}$ layer of silicon oil was added to limit evaporation and isotopic exchange with the atmosphere between sampling periods (Ingraham 1998). An identical bottle filled with water of known isotopic composition was set up outside the laboratory for one month with no more than a $0.2 \%$ ovariation in the isotopic signature.

Chloride samples were kept refrigerated in the laboratory and filtered using $0.45 \mu \mathrm{m}$ filters prior to analysis within two weeks of collection. Chloride concentration was determined using a Dionex ion chromatograph (IC). Stable-oxygen isotope analyses were performed on unfiltered water samples using a $\mathrm{CO}_{2}$ equilibration technique modified from Epstein and Mayeda (1953). Evacuated $5 \mathrm{~mL}$ test tubes with a septum cap (vacutainers used for blood work) were filled to $0.5 \mathrm{~atm}$ with $\mathrm{CO}_{2}$. Approximately $2.5 \mathrm{~mL}$ of sample was injected into the test tube and placed in an insulated bath $\left(22^{\circ} \mathrm{C}\right)$ on a shaker table overnight $(>12 \mathrm{hrs})$. Gas from the test tube was extracted on a high vacuum line, the $\mathrm{CO}_{2}$ was isolated cryogenically, and analyzed using a Thermo (Finnigan) isotope ratio mass spectrometer (IRMS) equipped with a dual inlet. The $\delta^{18} \mathrm{O}$ of the water sample $\left(\delta^{18} \mathrm{O}(\%)\right.$ $=\left[{ }^{18} \mathrm{O} /{ }^{16} \mathrm{O}_{\text {sample }} \div{ }^{18} \mathrm{O} /{ }^{16} \mathrm{O}_{\text {standard }}-1\right] \times 1000$ ) was calculated from the $\delta^{18} \mathrm{O}$ of the $\mathrm{CO}_{2}$ using a temperature dependent fractionation factor (Bottinga 1968) and reported relative to Vienna Standard Mean Ocean Water (VSMOW). Laboratory water standards were processed and analyzed in the same manner as samples for each batch of samples run.

Tritium samples were collected in May, 2004, from the 0.75 and $3.0-\mathrm{m}$ piezometers and from the lake. The piezometers were pumped dry and allowed to recover for one week before collecting $500 \mathrm{~mL}$ in glass bottles for tritium analyses.

Slug tests were performed at the end of the study on the 1.0, 2.0 and $3.0 \mathrm{~m}$ piezometers by pouring water into each piezometer to increase the head by a minimum of $2 \mathrm{~m}$, and recording recovery using the data-logging pressure transducers. Performance of a slug test in one piezometer in a nest did not measurably alter the head in the under or overlying piezometers within the period of testing. The Hvorslev method was used to determine hydraulic conductivities (Butler 1998).

\section{RESULTS}

Nest 3 was continuously flooded with at least $0.4 \mathrm{~m}$ of water during the year long study (Fig. 2). The water level at Nest 2 was at or above the ground surface $40 \%$ of the year, and $83 \%$ of the period of March through August when trees are actively growing (Keeland and Sharitz 1997). Nest 1 was flooded in late winter, but was otherwise usually dry.

\section{Hydraulic gradients and conductivity}

When water levels were high, hydraulic gradients determined from head measurements in the deeper piezometers were generally downward at all nests, with vertical gradients ranging from 0.05 to 0.2 . No consistent horizontal gradient was observed. When lake level fell, often below the ground surface at Nests 1 and 2, vertical and horizontal gradients were erratic with frequent reversals. The hydraulic conductivity measured in the nine piezometers at depths of 1.0, 2.0 and $3.0 \mathrm{~m}$ ranged over 5 orders of magnitude from $1 \times 10^{-7}$ to $3 \times 10^{-2} \mathrm{~cm} \mathrm{~s}^{-1}$ (Table 1), and showed no trend with depth or location.

\section{Oxygen isotopes}

Because the focus of this paper is on movement of water through the root zone under contin- 

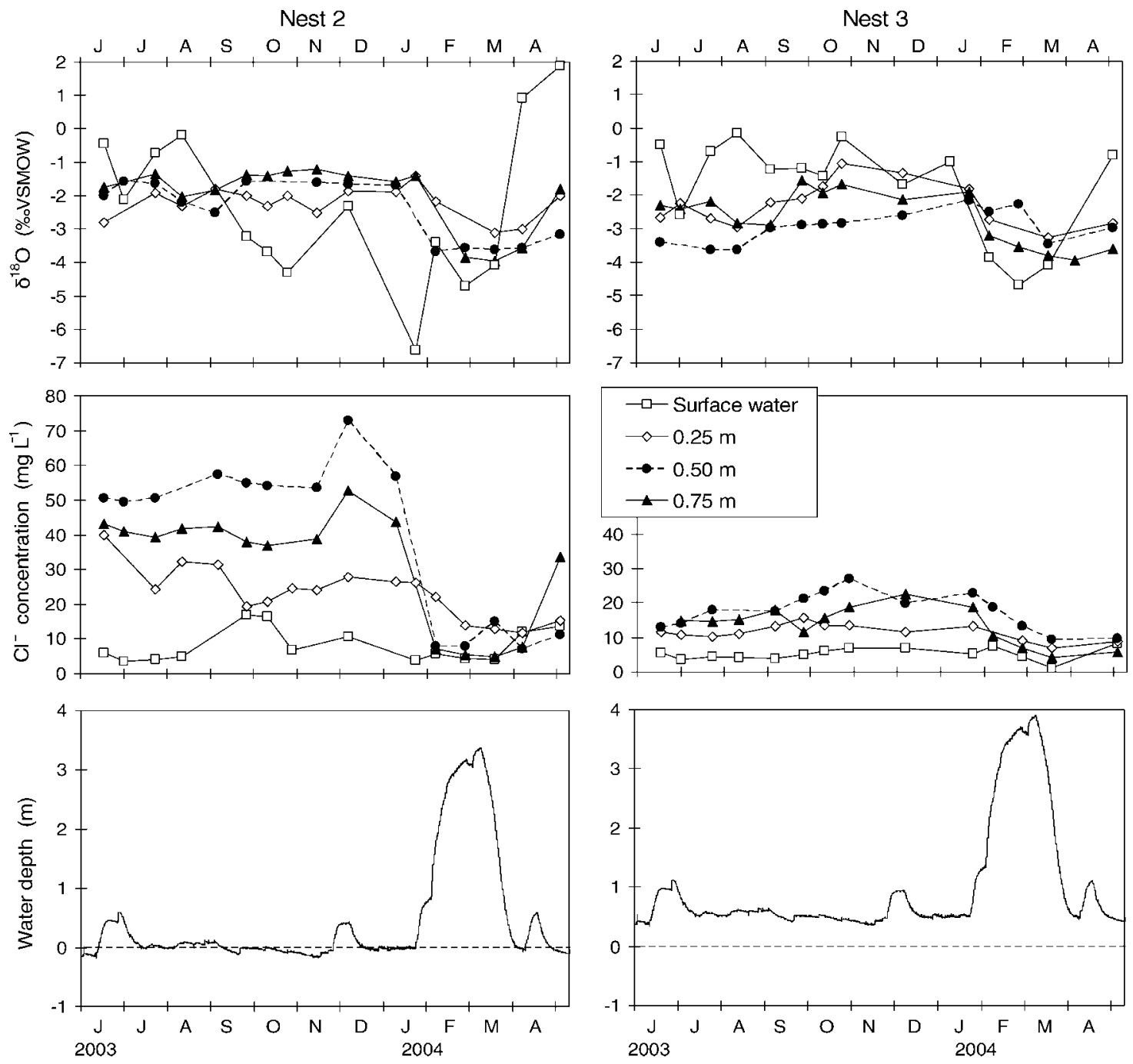

Figure 2. $\delta^{18} \mathrm{O}_{,} \mathrm{Cl}^{-}$concentration and water depth at piezometer Nests 2 and 3 . The ground surface is represented by a horizontal dashed line in the lower graphs.

uously or nearly continuously flooded conditions, only Nests 2 and 3 provided isotope and chemistry data that are pertinent. Nest 1 data is reported in Laine (2004).

Table 1. Hydraulic conductivities $\left(\mathrm{cm} \mathrm{s}^{-1}\right)$ determined from slug tests.

\begin{tabular}{cccc}
\hline Depth & Nest 1 & Nest 2 & Nest 3 \\
\hline $1.0 \mathrm{~m}$ & $3 \times 10^{-2}$ & $3 \times 10^{-5}$ & $4 \times 10^{-5}$ \\
$2.0 \mathrm{~m}$ & $2 \times 10^{-7}$ & $7 \times 10^{-3}$ & $2 \times 10^{-4}$ \\
$3.0 \mathrm{~m}$ & $5 \times 10^{-7}$ & $1 \times 10^{-7}$ & $9 \times 10^{-5}$ \\
\hline
\end{tabular}

The $\delta^{18} \mathrm{O}$ of precipitation and surface water varied seasonally (Fig. 2). During the winter rainy season, the $\delta^{18} \mathrm{O}$ of surface water fell around the weighted annual mean $\delta^{18} \mathrm{O}$ of precipitation of $-4.7 \%$ VSMOW. During the drier summer months, the lake level dropped below its surface outlet resulting in evaporative enrichment of ${ }^{18} \mathrm{O}$ in residual lake water. Most of the surface water $\delta^{18} \mathrm{O}$ values were between -2 and $+2 \%$ from April to August. Differences in the $\delta^{18} \mathrm{O}$ of surface water between Nests 2 and 3 were as high as 4\%o during periods when water at Nest 2 was only a 
few centimeters deep and not well mixed with lake water. When the water depth at Nest 2 was over $0.4 \mathrm{~m}$, differences in the $\delta^{18} \mathrm{O}$ of surface water between the two sites rarely exceeded $0.5 \%$.

Subsurface responses to changes in surface water composition were variable (Fig. 2). When water levels were low (June 2003 through January 2004), including two periods when surface water depths increased by more than $0.4 \mathrm{~m}$, the isotopic composition of piezometer samples showed no observable response to changes in surface water composition. Subsurface $\delta^{18} \mathrm{O}$ values during this time were all greater than $-3 \%$ o with the exception of the $0.25-\mathrm{m}$ piezometer at Nest 3.

In late January, 2004, water depth increased rapidly by more than $3 \mathrm{~m}$ with surface water $\delta^{18} \mathrm{O}$ values ranging between -3.4 and $-4.7 \%$. Following the increase in water depth, the $\delta^{18} \mathrm{O}$ of all piezometer samples declined in the direction of the new surface water values. At Nest 2 , the $\delta^{18} \mathrm{O}$ of water from the 0.50 and $0.75-\mathrm{m}$ depths decreased by 1.5 to $2.0 \%$ within the two-week sampling interval and remained similar to the surface water composition until the water level decreased. The $\delta^{18} \mathrm{O}$ signature from the $0.25-\mathrm{m}$ piezometer dropped by slightly over $1.0 \%$ over a longer period representing 4 to 6 weeks (4-week sample was lost).

At Nest 3, the 0.25 and $0.75-\mathrm{m}$ piezometers showed greater response than the $0.50-\mathrm{m}$ piezometer. The $\delta^{18} \mathrm{O}$ of water from 0.25 and $0.75 \mathrm{~m}$ decreased by approximately $2 \%$ following the increase in water depth. The initial decline began within the two-week sampling interval, but required more time than at Nest 2 to reach minimum $\delta^{18} \mathrm{O}$ values. At a depth of $0.75 \mathrm{~m}$, minimum values were reached approximately 8 weeks after the initial decline. The time required at $0.25 \mathrm{~m}$ was probably less, but data are not available for several of the intermediate sampling intervals. A rapid response may have also occurred at the $0.50-\mathrm{m}$ depth, but the $\delta^{18} \mathrm{O}$ values were already low at the start of the surface water rise, and subsequent changes were small.

\section{Chloride}

Changes in $\mathrm{Cl}^{-}$concentration were consistent with changes observed in $\delta^{18} \mathrm{O}$ (Fig. 2). Chloride concentrations in all piezometers were higher than in surface waters while surface water depth was low (June 2003 through January 2004), with no apparent communication between surface and subsurface water. With the late January rise in water level, a dramatic decline was observed in the $\mathrm{Cl}^{-}$ concentration in the 0.50 and $0.75-\mathrm{m}$ piezometers at Nest 2. Subsurface $\mathrm{Cl}^{-}$concentrations fell by as much as $90 \%$ to match surface water values. The response time was within a four-week sampling interval. As with the $\delta^{18} \mathrm{O}$ data, the response in the $0.25-\mathrm{m}$ piezometer was of lesser magnitude, and required greater time. Minimum $\mathrm{Cl}^{-}$values were observed more than 8 weeks after the initial water rise.

The $\mathrm{Cl}^{-}$concentrations at Nest 3 were much lower, which limited the magnitude of possible changes. The concentration of $\mathrm{Cl}^{-}$in surface and subsurface water appeared to be unrelated until the $3-\mathrm{m}$ rise in surface water in late January. All subsurface $\mathrm{Cl}^{-}$concentrations began to decline toward surface water values within the two-week sampling interval for the 0.50 and $0.75-\mathrm{m}$ piezometers, and within the four-week sampling interval for the $0.25-\mathrm{m}$ piezometer.

\section{Eh and pH}

Consistent analysis of Eh and $\mathrm{pH}$ was only possible during periods of high surface water level when water yield from the piezometers was high. During these times, pore water in the upper meter at all nests was mildly oxidizing with Eh values ranging from 160 to $310 \mathrm{mV}$. Surface water Eh varied within the same range during this time period. The $\mathrm{pH}$ of piezometer samples and surface water ranged from 6.4 to 8.0 with no apparent trend. During periods of low surface water level, water yield from piezometers was generally insufficient to collect all desired water quality parameters, and few Eh or $\mathrm{pH}$ measurements were made.

\section{Tritium}

Water from all sampled piezometers contained tritium at concentrations similar to surface water (Table 2). Tritium in piezometer samples 
Table 2. Tritium concentration (TU) of samples collected in May, 2004. The tritium concentration of lake water was 2.68 TU.

\begin{tabular}{lccc}
\hline Depth & Nest 1 & Nest 2 & Nest 3 \\
\hline $0.75 \mathrm{~m}$ & 3.07 & 2.86 & 2.60 \\
$3.0 \mathrm{~m}$ & 2.98 & 2.66 & 2.95 \\
\hline
\end{tabular}

was both slightly higher and slightly lower than surface water, with no consistent trend with depth.

\section{DISCUSSION}

Sky Lake is a perched hydrologic system where the bottom of the lake and wetland lie above the regional groundwater. This creates the potential for downward migration of surface water through the root zone. Head measurements over the study period revealed consistent downward hydraulic gradients at all three nests when lake levels were high, but gradients became erratic with frequent reversals when lake levels were low, suggesting that surface water is transported through the root zone primarily during periods of high water. Laine (2004) documented a strong correlation between local precipitation and surface water depth at Sky Lake, which means there is a plausible link between precipitation and increased downward flow of oxygenated surface water more conducive to tree growth.

The $\delta^{18} \mathrm{O}$ and $\mathrm{Cl}^{-}$results support this hypothesis. The isotopic and chemical composition of surface water and subsurface water appear to change independently when surface water depths are low (less than about $0.4 \mathrm{~m}$ at Nest 2). Rapid transport of surface water to a depth of at least $0.75 \mathrm{~m}$, however, is easily identified by the $\delta^{18} \mathrm{O}$ and $\mathrm{Cl}^{-}$data at Nest 2, and to a lesser degree at Nest 3, concurrent with the 3-m rise in lake level.

Elevated $\delta^{18} \mathrm{O}$ in the subsurface prior to the late-January rise in water level may reflect earlier infiltration of surface water during the summer when evaporation enriches the lake water in ${ }^{18} \mathrm{O}$. Elevated $\mathrm{Cl}^{-}$concentrations in the subsurface may result from evaporative concentration when pores partially drain, by receipt of agriculturally-affected runoff from surrounding fields, and by leaching from minerals. Pores at Nest 3 are rarely aerated, which may explain why $\mathrm{Cl}^{-}$concentrations at Nest 3 are considerably lower than at Nest 2.

The response to the $3-\mathrm{m}$ rise in lake level varied with depth at each piezometer nest. The muted response at depths of $0.25 \mathrm{~m}$ at Nest 2 and $0.50 \mathrm{~m}$ at Nest 3 suggests that there are preferential flow pathways through the sediment. Fast and slow flow pathways in variable directions are probably created by an abundance of buried and partially buried, decomposing tree limbs, trunks and roots. This is consistent with the 5 orders of magnitude variation in hydraulic conductivity measured in the deeper piezometers (Table 1).

The variability in conductivity is not caused by differences in sediment grain size. Cores up to $2 \mathrm{~m}$ in length collected from both the forested fringe and the open water environment contained silt and clay in relatively constant proportions with no interlayered sands (Galicki 2002). Most of the sediment is delivered to the wetland through lowenergy streams or backwater flows from the distant Yazoo River, resulting in little variation in sediment grain size. Erroneously high hydraulic conductivities could result from leakage around poorly sealed piezometers, but this is also not a likely explanation. The highest conductivities were measured at a depth of $1.0 \mathrm{~m}$ in Nest 1 and at $2.0 \mathrm{~m}$ in Nest 2. The slug tests were performed when water levels were below ground surface at these locations and water was added to raise the water level inside each of these piezometers well above the ground surface. Poor seals would have been evident by water seeping to the surface along the outside of these piezometers. The sediment is also plastic when wet, and deforms to fill voids.

The large range in hydraulic conductivity makes it impossible to determine a flux rate of water through the root zone using measured hydraulic gradients, but the isotope and chemistry data can be used to come up with an estimate. At Nest 2, $\mathrm{Cl}^{-}$concentrations clearly indicating the arrival of surface water are evident in samples collected four weeks after the rise in lake level (no data from two weeks after the initial rise), giving a maximum possible travel time to this depth. This yields a vertical travel rate, without regard to the actual travel path, of approximately $3 \mathrm{~cm} \mathrm{~d}^{-1}$. At Nest 3, decreasing $\delta^{18} \mathrm{O}$ values in response to the 
downward transport of surface water are evident at $0.75 \mathrm{~m}$ in samples collected two weeks after the water level rise, but values continued to decline toward surface water values up to 10 weeks after the rise in lake level. This yields a minimum travel rate closer to $1 \mathrm{~cm} \mathrm{~d}^{-1}$.

These rates are much faster than would be expected in typical clay-rich environments, but could be easily achieved under observed vertical gradients using the higher hydraulic conductivities reported in Table 1. If the root mass is concentrated in the upper 10 to $20 \mathrm{~cm}$ (Lugo 1984; Lugo et al. 1984), rising lake levels could deliver oxygenated surface water to roots within a few days, or even within hours of heavy or sustained precipitation.

Information on the oxygen concentration or Eh of pore water under variable water depths would be particularly useful here, but Eh data were only obtained during periods of high water when water yields from the piezometers were sufficient to collect all desired samples. Results from an earlier study at Sky Lake, may be used as indirect evidence of increasing oxygen concentrations in the root zone following precipitation-driven increases in surface water depth. Galicki (2002) made Eh measurements in freshly collected 1-m sediment cores from an area near Nest 2 when surface water was a few centimeters deep. The Eh was generally reducing, with most values falling below $-300 \mathrm{mV}$.

Pore water collected from the shallow piezometers during the high water interval in February and March, 2004, were all mildly oxidizing, with Eh values ranging from 160 to $310 \mathrm{mV}$. Surface water varied within the same range during this time period. In wetland sediments, higher Eh values indicate transport of oxygen to depth faster than it can be consumed by respiration or decomposition reactions. Reducing Eh when surface water levels are low, and mildly oxidizing Eh when water levels rise is consistent with the $\delta^{18} \mathrm{O}$ and $\mathrm{Cl}^{-}$data that suggest that rapid downward flow of surface water is only initiated when surface water reaches a threshold depth.

The tritium results confirm that pore water within the top $3 \mathrm{~m}$ is flushed at least annually. Water from all sampled piezometers contained tri- tium at concentrations similar to surface water ( $\mathrm{Ta}-$ ble 2). Differences between samples are probably the result of variability in precipitation rather than age because piezometer samples appear both slightly higher and slightly lower than surface water with no consistent trend with depth. During the year preceding this study, lake water levels were greater than $2 \mathrm{~m}$ for nearly 6 months. Transport of surface water to a depth of $3 \mathrm{~m}$ within 6 months requires a minimum travel rate on the order of 2 $\mathrm{cm} \mathrm{d}{ }^{-1}$, consistent with estimates using $\delta^{18} \mathrm{O}$ and $\mathrm{Cl}^{-}$data in the shallower piezometers.

Larger tree-ring widths in bald cypress from the continuously flooded region of Sky Lake are likely to correspond most directly with the occurrence and duration of surface water depths that exceed a threshold value ( $>1 \mathrm{~m}$ at Nest 3$)$ during the growing season. Water depth will generally correlate with precipitation, leading to a positive relationship between precipitation and tree-ring width. Exceptions may occur where frequent light rains do not substantially increase surface water depth, yet contribute to a high cumulative precipitation value.

Conflicting growth responses of bald cypress to increases in water depth reported by others (e.g. Keeland and Sharitz 1995; Young et al. 1995; Conner et al. 1997; Van Arsdale et al. 1998) may be partially the result of differing degrees of advective flow of oxygenated water through the root zone under the variable hydrogeologic conditions at each site. If increasing water depth does not enhance the transport of surface water through the root zone and adventitious roots are not plentiful, water depth should not be expected to be closely linked to growth.

\section{CONCLUSIONS}

The results of this study support the hypothesis that the correlation between precipitation and tree-ring width in continuously inundated bald cypress could be caused by initiation of vertical flow of surface water through the root zone. Dendroclimatic reconstruction, at least at Sky Lake, appears possible because increases in precipitation generally correlate well with increases in water 
level, which in turn enhances the delivery of oxygenated water to the roots.

The potential for enhanced transport of surface or groundwater through the root zone of a wetland following periods of higher precipitation will depend on the hydrogeologic setting of the wetland system. Hydrologically perched systems will be prone to downward flow of surface water when vertical gradients are increased by rising water levels. Other types of wetland systems may have different responses to precipitation.

\section{REFERENCES CITED}

Arthur, J. K.

2001 Hydrogeology, Model Description, and Flow Analysis of the Mississippi River Alluvial Aquifer in Northwestern Mississippi. USGS Water-Resources Investigations Report 01-4035.

Bottinga, Y.

1968 Calculation of fractionation factors for carbon and oxygen isotopic exchange in the system calcite-carbon dioxide-water. Journal of Physical Chemistry 72:800-807.

Brown, G. F.

1947 Geology and Artesian Water of the Alluvial Plain in Northwestern Mississippi. Mississippi Geological Survey Bulletin 65.

Butler, J. J., Jr.

1998 The Design, Performance, and Analysis of Slug Tests. Lewis Publishers, Boston.

Conner, W. H., K. W. McLeod, and J. K. McCarron

1997 Flooding and salinity effects on growth and survival of four common forested wetland species. Wetlands Ecology and Management 5:99-109.

Davidson, G. R., S. J. Bennett, W. C. Beard III, and P. Waldo

2005 Trace elements in sediments of an aging reservoir in rural Mississippi: potential for mobilization following dredging. Water, Air, and Soil Pollution 163: 281-292.

Dickson, R. E., and T. C. Broyer

1972 Effects of aeration, water supply, and nitrogen source on growth and development of tupelo gum and bald cypress. Ecology 53:626-634.

Dickson, R. E., T. C. Broyer, and C. M. Johnson

1972 Nutrient uptake by tupelo gum and bald cypress from saturated or unsaturated soil. Plant and Soil 37:297308.

Douglass, A. E.

1941 Crossdating in dendrochronology. Journal of Forestry 39:825-831.

Epstein, S., and T. Mayeda

1953 Variation of $\mathrm{O}^{18}$ content of waters from natural sources. Geochimica et Cosmochimica Acta 4:213-224.
Fisk, H. N.

1944 Geological Investigation of the Alluvial Valley of the Lower Mississippi River. US Department of Army, Mississippi River Commission.

Fritts, H. C.

1991 Reconstructing Large-Scale Climatic Patterns from Tree-Ring Data. University of Arizona Press, Tucson, Arizona.

Galicki, S. J.

2002 Bald Cypress Dendrochemistry and Sediment Geochemistry in a Lake Fringe Wetland, Sky Lake, Mississippi. Ph.D. dissertation, The University of Mississippi, Oxford.

Howler, R. H.

1972 The oxygen status of lake sediments. Journal of Environmental Quality 1:366-371.

Hoewler, R. H., and D. R. Bouldin

1971 The diffusion and consumption of oxygen in submerged soils. Soil Science Society of America Proceedings 35:202-208.

Ingraham, N. L.

1998 Isotopic variations in precipitation. In Isotope Tracers in Catchment Hydrology, edited by C. Kendall and J. J. McDonnell, pp. 87-118. Elsevier, New York.

Keeland, B. D., and R. R. Sharitz

1995 Seasonal growth patterns of Nyssa sylvatica var. biflora, Nyssa aquatica, and Taxodium distichum as affected by hydrologic regime. Canadian Journal of Forest Research 25:1084-1096.

Keeland, B. D., and R. R. Sharitz

1997 The effects of water-level fluctuations on weekly tree growth in a southeastern USA swamp. American Journal of Botany 84:131-139.

Laine, B. C.

2004 Hydrologic Controls on Wetland Tree Growth: Determining the Origin, Residence Time and Water Quality of Groundwater in the Shallow Root Zone. M.S. thesis, The University of Mississippi, Oxford.

Lugo, A. E.

1984 Review of early literature on forested wetlands in the United States. In Cypress Swamps, edited by K. C. Ewel and H. T. Odum, pp. 7-15. University of Florida Press, Gainesville.

Lugo, A. E., J. K. Nessel, and T. M. Hanlon

1984 Root distribution in a north-central Florida cypress stand. In Cypress Swamps, edited by K. C. Ewel and H. T. Odum, pp. 279-285. University of Florida Press, Gainesville.

Pezeshki, S. R.

1991 Root responses of flood-tolerant and flood-sensitive tree species to soil redox conditions. Trees 5:180186.

Pezeshki, S. R., and M. I. Santos

1998 Relationships among rhizosphere oxygen deficiency, root restriction, photosynthesis, and growth in baldcypress (Taxodium distichum L.) seedlings. Photosynthetica 35:381-390. 
Stahle, D. W., and M. K. Cleaveland

1992 Reconstruction and analysis of spring rainfall over the southeastern U.S. for the past 1000 years. Bulletin American Meteorological Society 73:1947-1961.

Stahle, D. W. and M. K. Cleaveland

1996 Large-scale climatic influences on baldcypress tree growth across the southeastern United States. In Climatic Variations and Forcing Mechanisms of the Last 2000 Years, edited by P. D. Jones, R. S. Bradley, and J. Jouzel, pp. 125-140. Springer, New York.

Stahle, D. W., M. K. Cleaveland, and J. G. Hehr

1985 A 450-year drought reconstruction for Arkansas, United States. Nature 316:530-532.
Stahle, D. W., M. K. Cleaveland, and J. G. Hehr

1988 North Carolina climate changes reconstructed from tree rings: A.D. 372 to 1985. Science 240:15171519.

Van Arsdale, R. B., D. W. Stahle, M. K. Cleaveland, and M. J. Guccione

1998 Earthquake signals in tree-ring data from the New Madrid seismic zone and implications for paleoseismicity. Geology 26:515-518.

Young, P. J., B. D. Keeland, and R. R. Sharitz

1995 Growth response of bladcypress [Taxodium distichum (L.) Rich.] to an altered hydrologic regime. The American Midland Naturalist 133:206-212.

Received 14 August 2005; accepted 3 March 2006. 